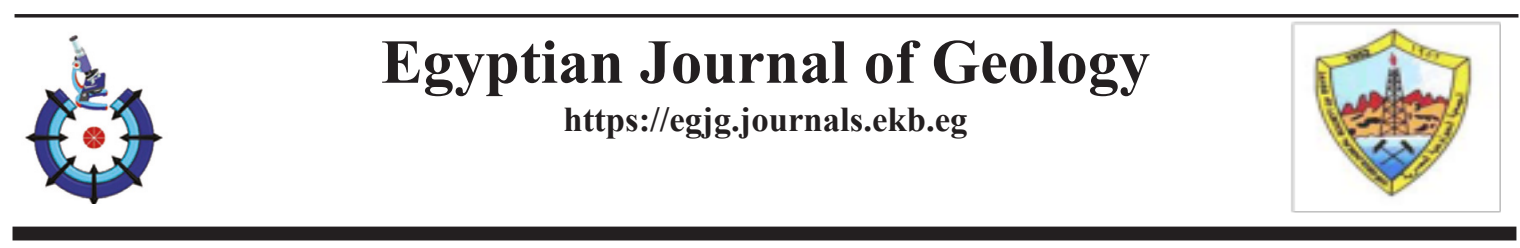

\title{
Cusum Usage for Environmental Assessment of Kuwait South Coastal Waters
}

\author{
Alajmi, Abdulrahman Jluwi*, Al-Rashed, Ahmed Rashed and Al-Hamad, Youssef \\ Mohammad \\ Science department, Faculty of Basic Education, The Public Authority for Applied \\ Education and Training, Ardiya, Kuwait
}

\begin{abstract}
$\mathbf{T}$ HE growth and development of the south coastal areas of Kuwait as a result of high industrialization and urbanization set a severe stress on the near shore fragile environment of Kuwait. The south coastal environment is subjected to pollution of coastal waters. Oil spills, industrial wastes and thermal pollution form power plants and factories, fecal coliform and solid waste. These pollutants have environmental impacts on health and functional integrity of the coastal and marine ecosystems. In this study, recent methods will be used to monitor the quality of south coastal water and their environmental condition. These methods are used to measure the pollution and environmental indicators by Environmental Protection Agency of Kuwait (EPA) to monitor the quality of south coastal water. Finally, an assessment process of the quality, costal water monitoring system and pollution levels measurements can help decision maker and planner in solving serious environmental problems associated with the south coastal developments. The south coastal water analysis showed high level of bacteria (T.C, F.C and F.S).
\end{abstract}

Keywords: Kuwait, industrialization, urbanization, coastal water, pollution.

\section{Inroduction}

The State of Kuwait is situated at the northwestern corner of the Arabian Gulf, between latitudes $28^{\circ} 30^{\prime} \mathrm{N}$ and $30^{\circ} 05^{\prime} \mathrm{N}$ and longitudes $46^{\circ} 33^{\prime} \mathrm{E}$ and $8^{\circ} 35^{\prime} \mathrm{E}$ (Fig. 1).

Kuwait has a coastline of around $500 \mathrm{Km}$ in length and includes nine islands. In Kuwait, oil revenues allow rapid economic expansion. New harbors, and the extension of existing coastal facilities, power plants, desalination units, petrochemical industries, oil refineries, commercial ports and loading facilities, have all been developed and will continue to be under planning and construction to satisfy human needs and attain social welfare. Rapid coastal developments may have adverse impacts on the coastal and marine environments. These environmental impacts may seriously affect the health and functional integrity of the natural coastal and marine ecosystems. The growth in coastal development has increased pressure on the coastal environment and led to an increase in the pollution of coastal waters. Coastal water pollutants come from land and sea sources.

The main sources of coastal pollution (EPA 2019) are:

- Industrial, agricultural, and municipal waste from run-off and storm water channels.

- Industrial and municipal waste discharged from sewage outfall pipes.

- Deliberate dumping and discharge from vessels of domestic waste, oily bilge water and tank washings.

- Accidental discharge of oil from vessels following collision or grounding. 


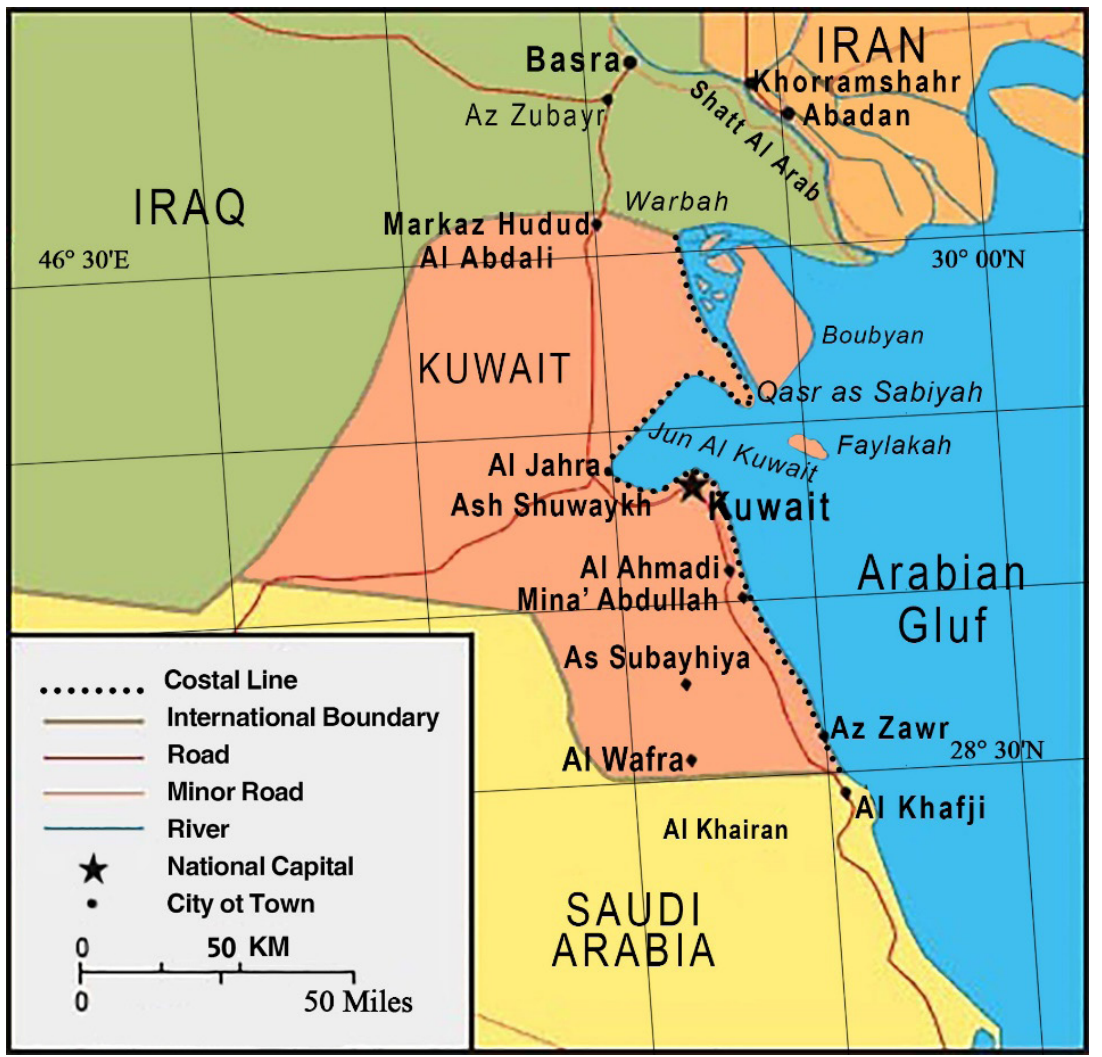

Fig. 1. Location Map of the Kuwait showing the costal line.

Legislation has been introduced here in Kuwait over recent years (EPA 2000) to control both land and sea sources of coastal water pollution. However, illegal discharge of oily wastewater, domestic municipal waste dumping and accidental spillage from vessels and the problem of waste from sewage, run-off and storm water channels continue to affect coastal water.

Protection of water resources requires detailed water quality monitoring and assessment information to verify that the resource management activities are effective and that there is a progress toward ensuring that the waters of Kuwait are fishable and swimmable and that aquatic environments are healthy. Monitoring provides the information to identify impacts on water-dependent resources and the causes and sources of impairments. There are many ways to monitor coastal water conditions (Clccio, 1998). Chemical measurements are used to monitor the constituents in water, sediments, and fish tissue (i.e., levels of dissolved oxygen, suspended sediments, nutrients, metals, oils, and pesticides). Assessment of monitoring data helps identify trends in water quality and the effectiveness of management measures. For example, it helps determine whether water quality standards are being met and whether these standards are adequate to protect marine resources (WHO 2017).

In common with many countries, Kuwait has developed marine monitoring programs over several years in response to environmental events or proposed construction in the coastal zone (Abou- Seido, and Asarawi, 1990). Such monitoring programs provide useful data on the state of the environment in terms of hydrocarbons, metals, bathing beach quality and harmful algal blooms and may allow some conclusions to be drawn about trends in changes of environmental quality.

There are many local agencies in Kuwait are responsible for monitoring water quality. State pollution control agencies such as EPA (2017) have key monitoring responsibilities conduct vigorous monitoring programs. They receive pollution control and environmental management grants from Kuwait government that help them to establish and maintain monitoring programs and report the results of monitoring activities to the government. 
The EPA usually monitors marine water quality in Kuwait territorial waters. The bacterial indicators were usually collected from the following permanent locations on Kuwait coastal zones. These zones are: Al-Fahaheel (zone 1), Mina Al-Ahmadi (zone 2), Shuaiba (zone 3), Mina Abdallah, Al-Zour (zone 4) and AL-Khiran (zone 5) (Fig. 2).

Monitoring can be conducted for many purposes. Five major purposes are to:

1. Characterize waters and identify changes or trends in water quality over time.

2. Identify specific existing or emerging water quality problems.

3. Gather information to design specific pollution prevention or remediation programs.

4. Determine whether program goals, such as compliance with pollution regulations or implementation of effective pollution control actions are being met and applied.

5. Respond to emergencies, such as spills and floods.
Polluted runoff and untreated sewage released into the water can expose swimmers to bacteria, viruses, and protozoans. These pathogens (disease-causing organisms) can be present at or near the site where polluted discharges enter the water. Children, the elderly, and people with weakened immune systems are most likely to develop illnesses or infections after swimming in polluted water. Swimming-related illnesses are typically minor. This means that they require little or no treatment, respond readily to treatment, and have no long-term health effects. The most common illness associated with swimming in water polluted by sewage gastroenteritis. It occurs in a variety of forms that can have one or more of the following symptoms: nausea, vomiting, stomachache, diarrhea, headache, and fever. Other minor illnesses associated with swimming include ear, eye, nose, and throat infections. In highly polluted water, swimmers may occasionally be exposed to more serious diseases like dysentery, hepatitis, cholera, and typhoid fever (WHO, 2017).

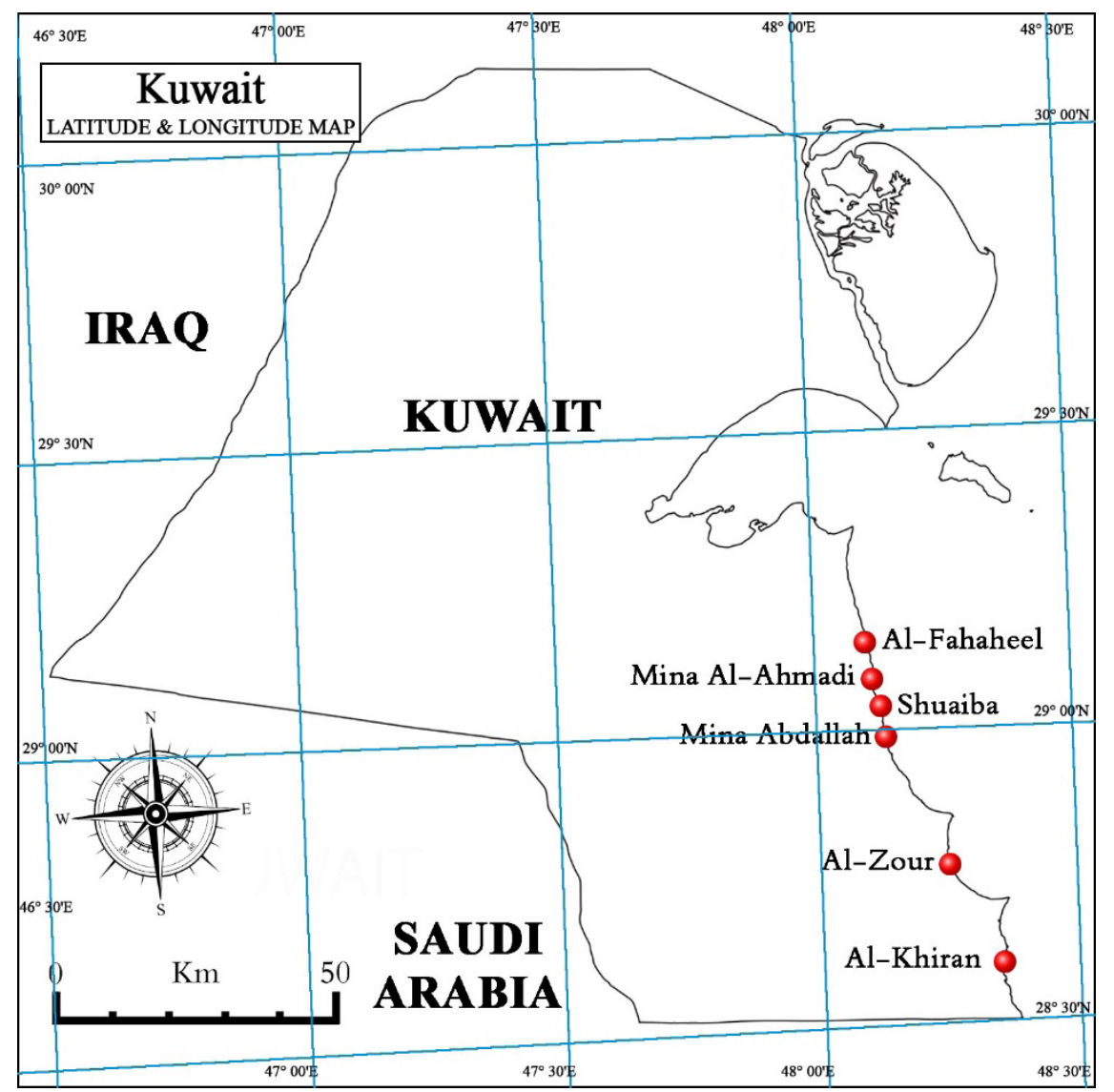

Fig. 2. Location map of the EPA monitoring areas, south coast of Kuwait. 
This paper aims to identify the existing environmental conditions of Kuwait coastal waters to attain better water quality monitoring system to help the decision-makers and planners in identifying the serious environmental problems associated with coastal developments.

\section{Materials and Methods}

In the monitoring procedure water samples were taken from the six zones in the south coastal area of Kuwait (Fig 2). The samples were analyzed to measure the level of bacteria (e.g.: total coliform fecal streptococci). Subsurface coastal seawater samples were collected within 2 meters from the coast and at depth of $25 \mathrm{~cm}$ from water surface (Fig. 3).
Each sample was collected inside sterilized dark bottle. This bottle was sterilized at the microbiology lab of EPA in Kuwait using autoclave. During the sampling from the sea water the bottle is open under the water surface using sticks shown in Figure 3. The bottle must be filled about three quarter and eve vacuum in it. After backing up from water the bottle should be close tightly and kept in ice to keep bacteria live and not destroyed.

Each bottle was labeled with the day and date. Air and water temperature weather conditions of the sea are recorded on a-day basis, membrane filtration technique was used to analyze each sample.

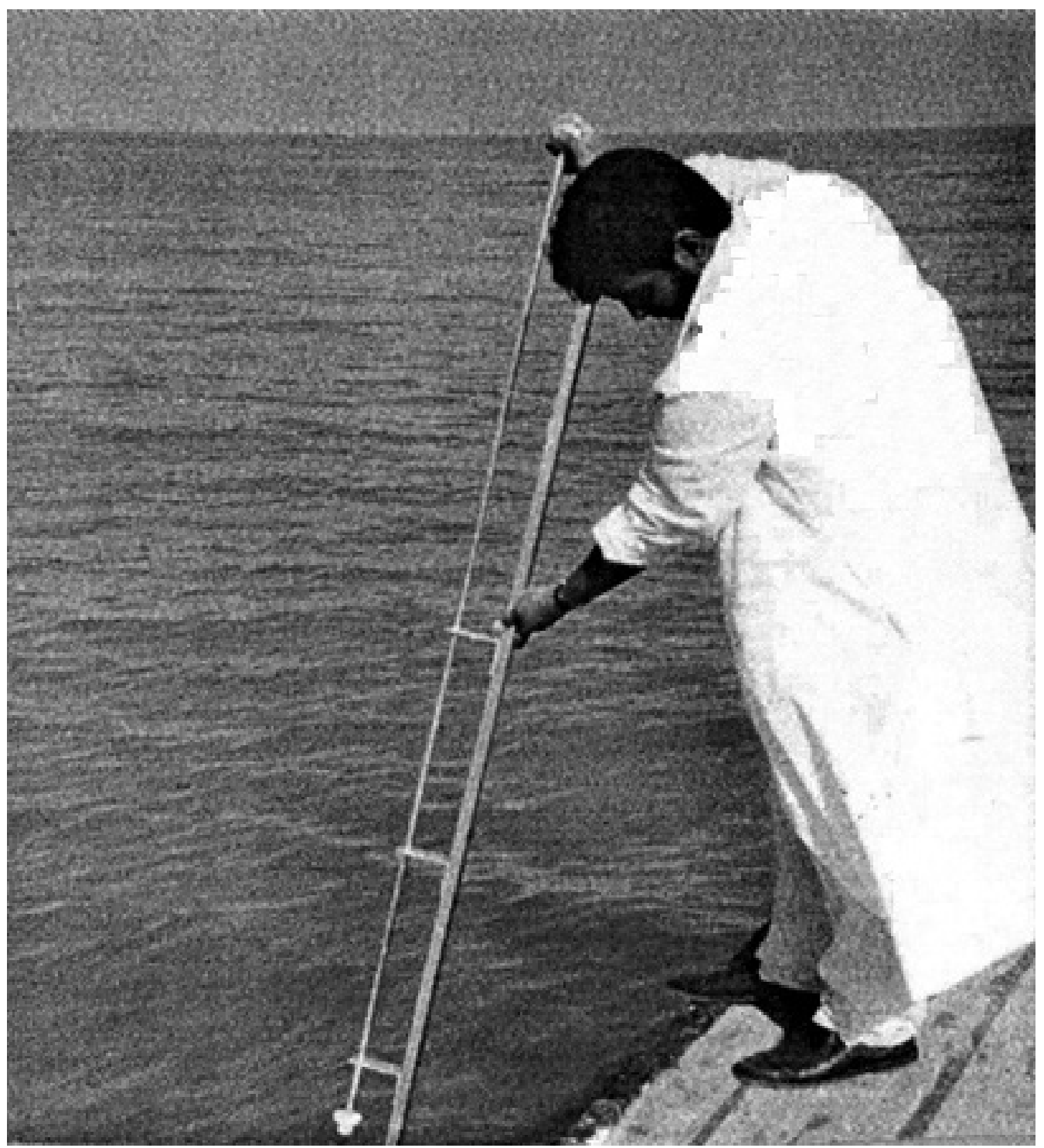

Fig. 3. Subsurface sampling of seawater using sticks.

Egypt. J. Geo. Vol. 65 (2021) 


\section{Cusum Method}

Cumulative Sum (CUSUM) method was developed for monitoring industrial production. This method has long been used in the industrial setting since the 50's as a diagnostic and monitoring tool for quality control. It tracks changes in a variable of interest relative to a baseline value.

The basic idea underlying this method is that one keeps a running record of the deviations of the quality parameter at any time based on a sample of $\mathrm{N}$ from the population, and if the quality parameter suddenly shifts or gradually drifts away from the desired quantity, then a warning is issued, the process is halted, and reasons are sought for the change. The deviations are expressed in terms of statistic deviation, and reasons are sought for the change. The deviations are expressed in terms of standard errors, that is, the observed value minus the desired (on target) value divided by the standard error (standard deviation divided by the square root of the sample size N). If, as in most water quality monitoring applications, one wants to detect increasing trends, then a succession of upwardly biased results will push the cumulative sum toward an upper warning level. An on-target process will have sequences of positive and negative deviations that in principle generally cancel out any upward trend.

Many researchers applied CUSUM method in other fields. Levin and Kline (Levin, Kline, 1985) modified CUSUM method for use in temporal analysis of epidemiological data. The modified CUSUM monitors the pattern of disease over time in group-level data (case and population at-risk counts). The CUSUM accumulates deviations from a baseline disease occurrence over time. It allows rapid measurement of change from historical case counts. The statistic magnifies small, abrupt changes. Only when the CUSUM exceeds a chosen threshold, used to create an "indifference zone", is the value added to the running cumulative sum. Small rises in disease occurrence do not register, limiting the chance for false positives.

Manly (1994) presented an adaptation of the CUSUM method that could be used in the environmental setting to detect systematic changes in one or more monitored variables, at more than one site. He considered the situation where monitoring is being performed at several independent sites, with data being collected at regular time intervals and illustrated the method using data collected on water quality variables from 48 Norwegian lakes over a 4-year period. The observations from each station could be independently randomized in time to generate data sets that have no underlying systematic changes present. By comparing the observed data to the randomized data, conclusions can be made as to whether there is any evidence of a systematic change occurring. Plots of the CUSUM for each year can be used to determine the type of changes that appear to be taking place.

Manly and Mackenzie (2000) have recently shown that the CUSUM approach has good power to detect a common time-trend over a number of independent sites and for detecting different time-trends for each site, which would result in a change in the overall variance of the process. They have also shown that the CUSUM approach compares favorably to existing parametric and non-parametric methods with one major advantage being the simple extension to allow for serial correlation in the data. The modified CUSUM method is robust to high levels of serial correlation with only slight loss of power.

The CUSUM Analysis Tool (CAT) was developed to enable researchers to use the cumulative-sum methods in a user-friendly, Windows environment, in trend testing. However, CAT has not been designed to produce professional looking reports and it is recommended that a word processor be used for this purpose. Results from the output window and CUSUM plots can be easily transferred into a word processor using the copy and paste commands. Both the univariate and multivariate analysis options are available in CAT, with up to 10 variables able to be analyzed from up to 100 stations and 50 years' worth of data.

\section{Results and Discussion}

The temporary and spatial variation of the pollutant levels measured offshore of the Kuwaiti coast are mainly dependent on the characteristics of the onshore pollutant's sources (i.e., locations, pollutant types, quantity of pollution, and the rate of discharge) and prevailing hydrographical behavior within Kuwait territorial waters (EPA 2000). The monthly average field measurement during the last five years (i.e., from 2014 to2019) for bacterial indicator species (i.e., total coliform (TC), fecal coliform (FC), and fecal streptococci (FS)) were collected and documented. Based on the five years of data measurements, the monthly 
levels of specified indicators are presented in chart (1a-b) and (Table 1). These measurements were evaluated and compared with the EPA standards. Generally, it was found that, the bacterial pollutants during the first three years of the studying period between 2014-2017 have higher level comparing with environmental protection agency of Kuwait limits (Table 2). In the years from 2017 to 2019, these parameters decreased to within the Kuwait EPA standards, (chart, 2 and Table, 3). The standard gives 1000 cfu/100 ml total coliform (TC), $200 \mathrm{cfu} / 100 \mathrm{ml}$ for fecal coliform (FS) and, fecal streptococci (FC).

TABLE 1.The monthly average (cfu/100 ml) levels of specific indicators (2014-2019).

\begin{tabular}{|c|c|c|c|c|c|c|c|c|c|c|c|c|c|}
\hline $\begin{array}{l}\text { Lo c a - } \\
\text { tion }\end{array}$ & $\begin{array}{l}\text { Indica- } \\
\text { tor }\end{array}$ & Jan & Feb & Mar & Apr & May & Jun & Jul & Aug & Sep & Oct & Nov & Dec \\
\hline \multirow{3}{*}{$\begin{array}{c}\text { Al-Faha- } \\
\text { heel }\end{array}$} & $\mathrm{TC}$ & 1800 & 11300 & 2300 & 465 & 944 & 750 & 5000 & 650 & 2000 & 2200 & 2300 & 2400 \\
\hline & $\mathrm{FC}$ & 130 & 1131 & 313 & 20 & 185 & 80 & 250 & 80 & 40 & 60 & 70 & 80 \\
\hline & FS & 90 & 1900 & 26 & 24 & 89 & 90 & 100 & 100 & 100 & 150 & 120 & 160 \\
\hline \multirow{3}{*}{$\begin{array}{l}\text { Mina } \\
\text { Al-Ah- } \\
\text { madi }\end{array}$} & $\mathrm{TC}$ & 600 & 5.800 & 1200 & 305 & 500 & 250 & 75 & 965 & 4850 & 3200 & 5000 & 5300 \\
\hline & $\mathrm{FC}$ & 65 & 2300 & 85 & 38 & 35 & 30 & 22 & 25 & 50 & 30 & 60 & 70 \\
\hline & FS & 30 & 350 & 27 & 20 & 35 & 20 & 15 & 22 & 42 & 31 & 50 & 80 \\
\hline \multirow{3}{*}{ Shuaiba } & $\mathrm{TC}$ & 450 & 750 & 500 & 300 & 300 & 400 & 300 & 300 & 750 & 9507 & 800 & 10000 \\
\hline & $\mathrm{FC}$ & 70 & 150 & 42 & 24 & 20 & 25 & 20 & 10 & 100 & 200 & 110 & 220 \\
\hline & FS & 100 & 90 & 85 & 15 & 20 & 35 & 15 & 25 & 15 & 30 & 20 & 30 \\
\hline \multirow{3}{*}{$\begin{array}{l}\text { Mina } \\
\text { Abdal- } \\
\text { lah }\end{array}$} & $\mathrm{TC}$ & 320 & 123 & 3000 & 300 & 420 & 500 & 330 & 415 & 1200 & 12690 & 12500 & 12800 \\
\hline & $\mathrm{FC}$ & 100 & 4850 & 250 & 20 & 15 & 25 & 30 & 20 & 100 & 416 & 120 & 500 \\
\hline & FS & 23 & 2500 & 40 & 15 & 10 & 30 & 30 & 30 & 150 & 320 & 160 & 330 \\
\hline \multirow{3}{*}{ Al- Zour } & $\mathrm{TC}$ & 400 & 18300 & 1057 & 330 & 410 & 426 & 300 & 340 & 500 & 850 & 520 & 900 \\
\hline & $\mathrm{FC}$ & 100 & 8,421 & 80 & 10 & 30 & 25 & 24 & 20 & 10 & 225 & 20 & 300 \\
\hline & F S & 20 & 2450 & 75 & 13 & 25 & 30 & 15 & 25 & 20 & 50 & 30 & 60 \\
\hline \multirow{3}{*}{$\begin{array}{c}\text { Al- } \\
\text { Khiran }\end{array}$} & $\mathrm{TC}$ & 800 & 2550 & 1570 & 260 & 750 & 650 & 400 & 300 & 6540 & 1000 & 7000 & 8000 \\
\hline & $\mathrm{FC}$ & 50 & 520 & 130 & 16 & 90 & 13 & 24 & 25 & 30 & 50 & 40 & 60 \\
\hline & F S & 50 & 500 & 50 & 22 & 125 & 90 & 44 & 30 & 35 & 500 & 40 & 80 \\
\hline
\end{tabular}

TABLE 2. Bacterial indicators (cfu/100 ml) range at different locations on Kuwait coastal waters (2014-2019).

\begin{tabular}{|c|c|c|c|c|c|c|c|}
\hline \multirow{2}{*}{ No. } & \multirow{2}{*}{ location } & \multicolumn{2}{|c|}{ T.C } & \multicolumn{2}{c|}{ F.C } & \multicolumn{2}{c|}{ F.S } \\
\cline { 2 - 7 } & & $\min$ & $\mathbf{m a x}$ & $\mathbf{m i n}$ & $\mathbf{m a x}$ & $\min$ & $\max$ \\
\hline $\mathbf{1}$ & Al-Fahaheel & 138 & 946 & 15 & 2,003 & 10 & 300 \\
\hline $\mathbf{2}$ & Mina Al-Ahmadi & 60 & 5200 & 10 & 2,200 & 8 & 280 \\
\hline $\mathbf{3}$ & Shuaiba & 250 & 8,507 & 80 & 95 & 15 & 90 \\
\hline $\mathbf{4}$ & Mina Abdallah & 110 & 11,500 & 8 & 3,520 & 5 & 2,300 \\
\hline $\mathbf{5}$ & Al-Zour & 300 & 16,500 & 15 & 7,600 & 20 & 2,200 \\
\hline $\mathbf{6}$ & Al-Khiran & 520 & 6,100 & 25 & 420 & 25 & 440 \\
\hline
\end{tabular}

Egypt. J. Geo. Vol. 65 (2021) 


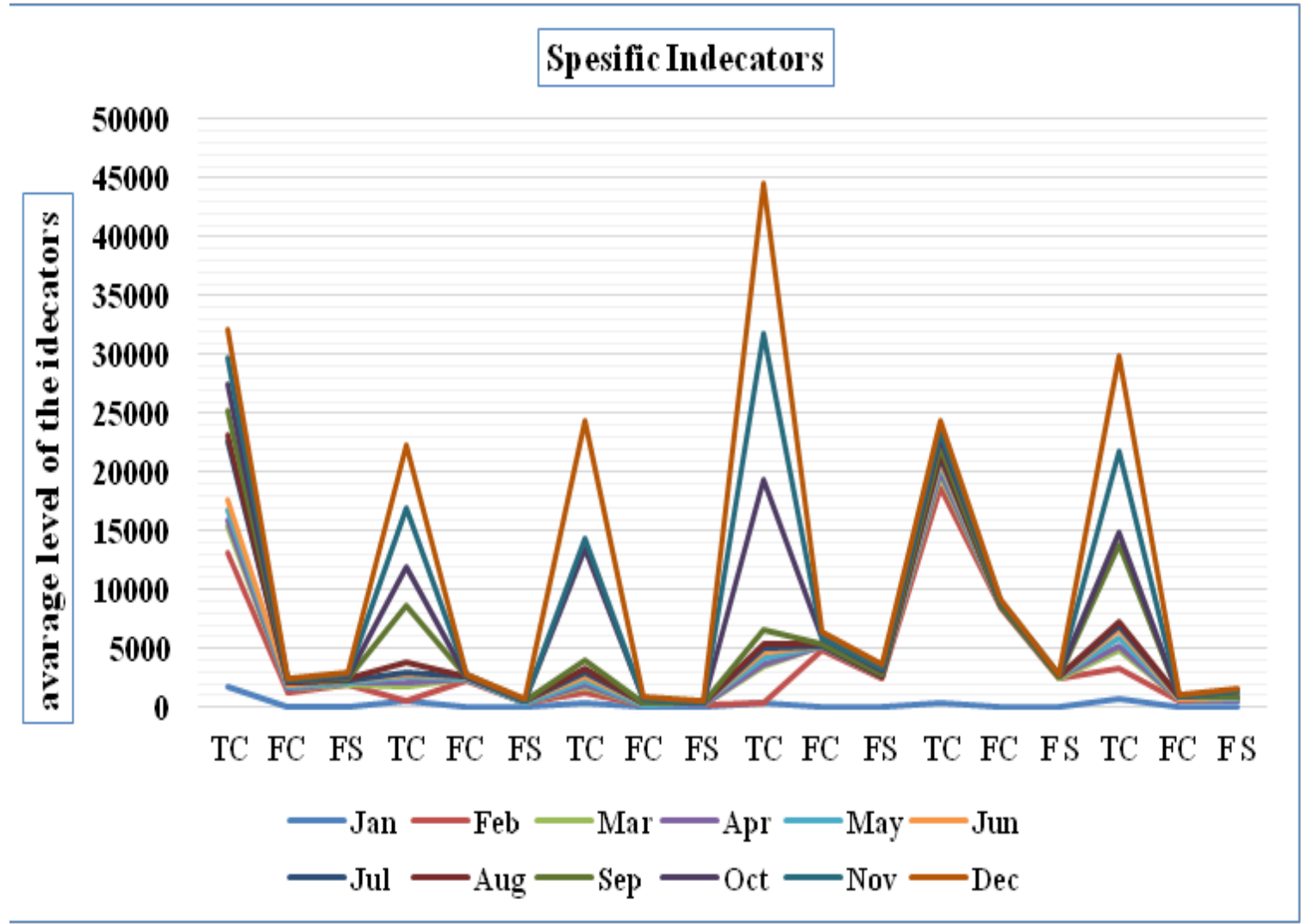

Chart (1a). Bacterial indicators (cfu/100 ml) at different location south coast of Kuwait.

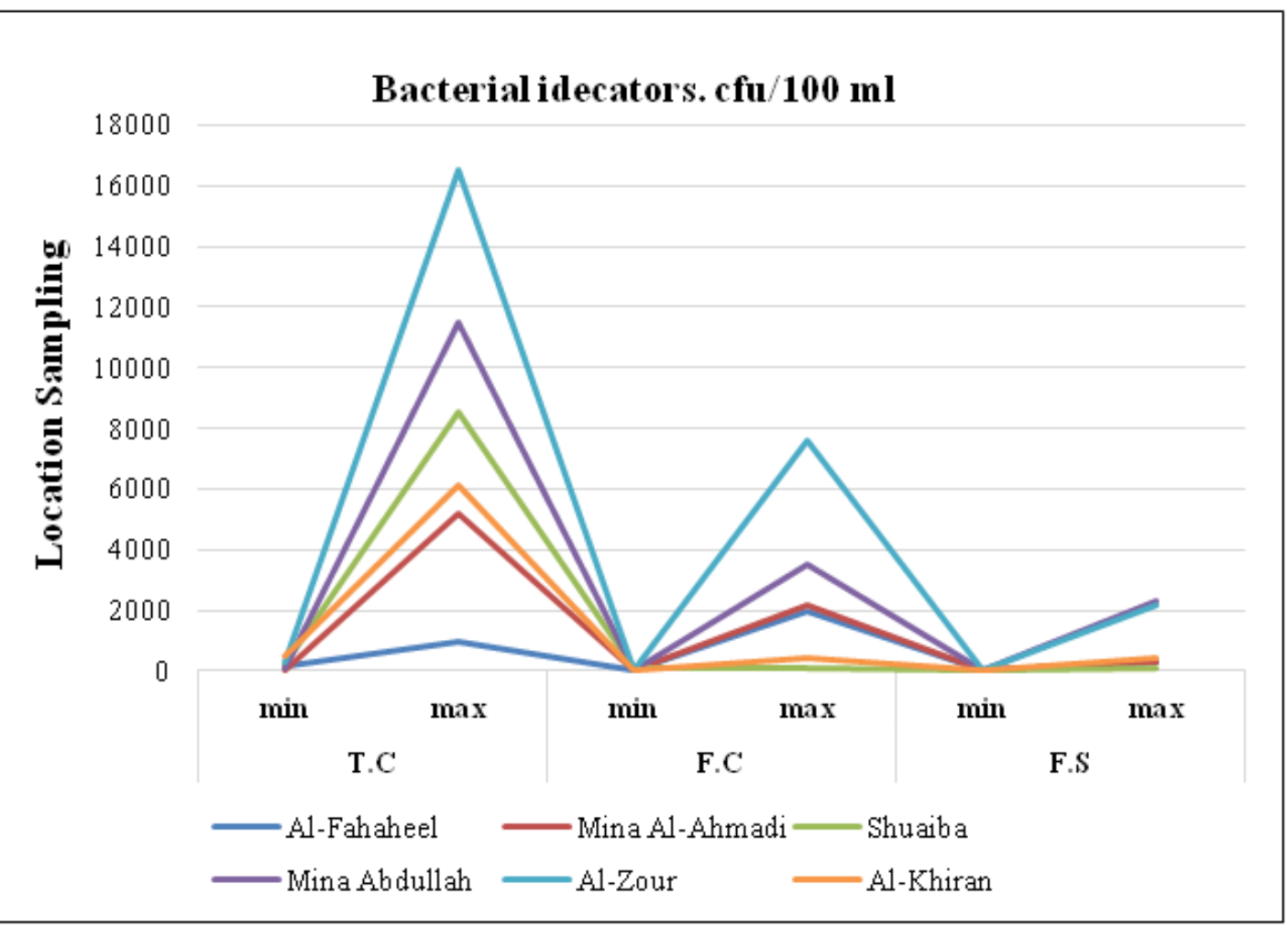

Chart (1b). the monthly average levels of Bacterial indicators (cfu/100 ml). 
TABLE 3. Bacterial indicators (cfu/100 ml) limits according to environmental protection agency of Kuwait.

\begin{tabular}{|c|c|c|c|c|c|c|c|}
\hline \multicolumn{2}{|c|}{ T.C } & \multicolumn{2}{c|}{ F.C } & \multicolumn{2}{c|}{ F.S } & \\
\hline location & No. & Min & Max & Min & Max & Min & Max \\
\hline Al-Fahaheel & 1 & 120 & 7520 & 15 & 1500 & 5 & 160 \\
\hline Mina & 2 & 40 & 3200 & 10 & 1020 & 3 & 200 \\
\hline Al Ahmadi & 3 & 200 & 6420 & 80 & 60 & 10 & 60 \\
\hline Shuaiba & 4 & 100 & 10200 & 8 & 2325 & 3 & 1650 \\
\hline Mina Abdallah & 5 & 250 & 14100 & 15 & 4500 & 15 & 1320 \\
\hline Al-Zour & 6 & 400 & 5050 & 25 & 251 & 10 & 330 \\
\hline Al-Khiran & & & & & & & \\
\hline
\end{tabular}

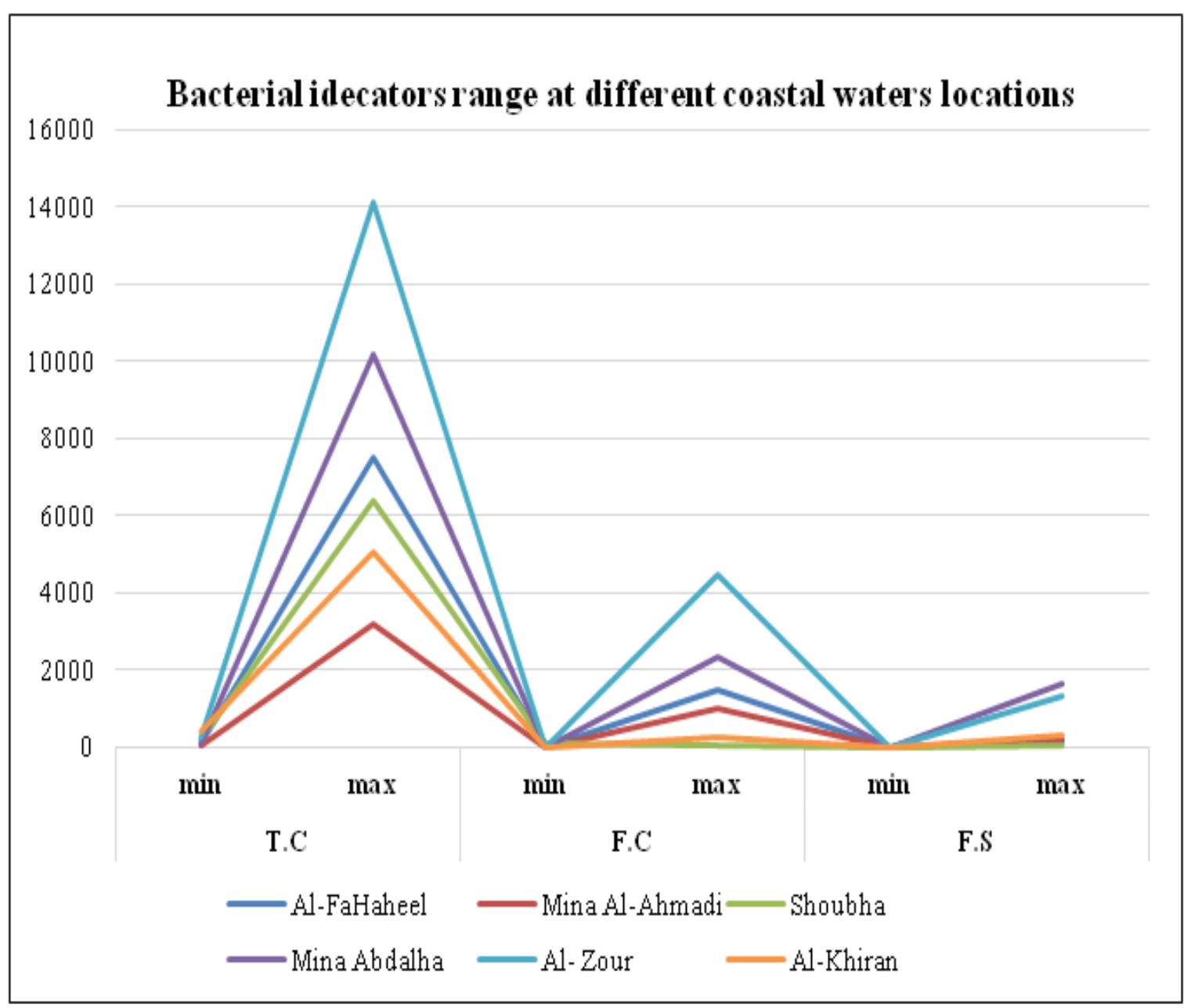

Chart 2. Bacterial indicators (cfu/100 ml) range at different locations on Kuwait coastal waters according to EPA of Kuwait.

Egypt. J. Geo. Vol. 65 (2021) 
The environmental indicators can be defined as measurable features which singly provide scientifically useful evidence of environmental and ecosystem measurable quality of pollution. In the years before 2017 there were no improvements in water -quality monitoring system in Kuwait. During the flowing years evaluation of water-quality condition was implemented using Geographic Information system (GIS). Special water protection plans developed to enhanced water protection near the industrial areas which considers the major reasons for increasing the pollution and the level of biological indicators. This explains the drop in the measurement of the biological indicators to meet the limits of the environmental protection agency in the years following 2017. In parallel with the previous action, the ministry of interior established environmental police department for environmental law enforcement to deal with all environmental legal issues in order of keeping more than 300 kilometers of the coastal area protected from any industrial assault against the marine waters and life.

Water hydrodynamic behavior in Kuwait coast

The main hydrodynamic factors affect the Kuwait coast are tidal currents water variation and waves. The water levels variations are mostly semidiurnal with maximum tidal range of $3.0 \mathrm{~m}$ along the south coast. Due to high temperature, evaporation, and semi closed body of water of the Arabian Gulf the waves current coming from the Indian Ocean to the gulf have low Anti-clockwise pattern. This kind of current eliminates the cleanup of natural process that is usually currents can do in any open waters. Tidal waves flow adjacent to the coastal area with speed average $1 \mathrm{~m} / \mathrm{s}$ is not real able for local natural cleaning of the water body south coast of Kuwait (Fig. 4a-b). Such behavior element the amount of the dischargeable contaminants in the coast, more pollutants will accumulate in the in the area.

\section{Cusum method analysis}

It was mentioned earlier in this paper that cumulative Sum (CUSUM) method has different applications, one of these is the environmental setting to (Wetherington, 2010) detect systemic changes in one or more monitored variables at more than one site (chart 3 ). The observations from each station could be independently randomized in time to generate data sets that have no under lying systematic changes present. By comparing the observed data to randomized data, conclusion can be made as whether there is any evidence of systematic changes occur (Biswas et al., 2016).

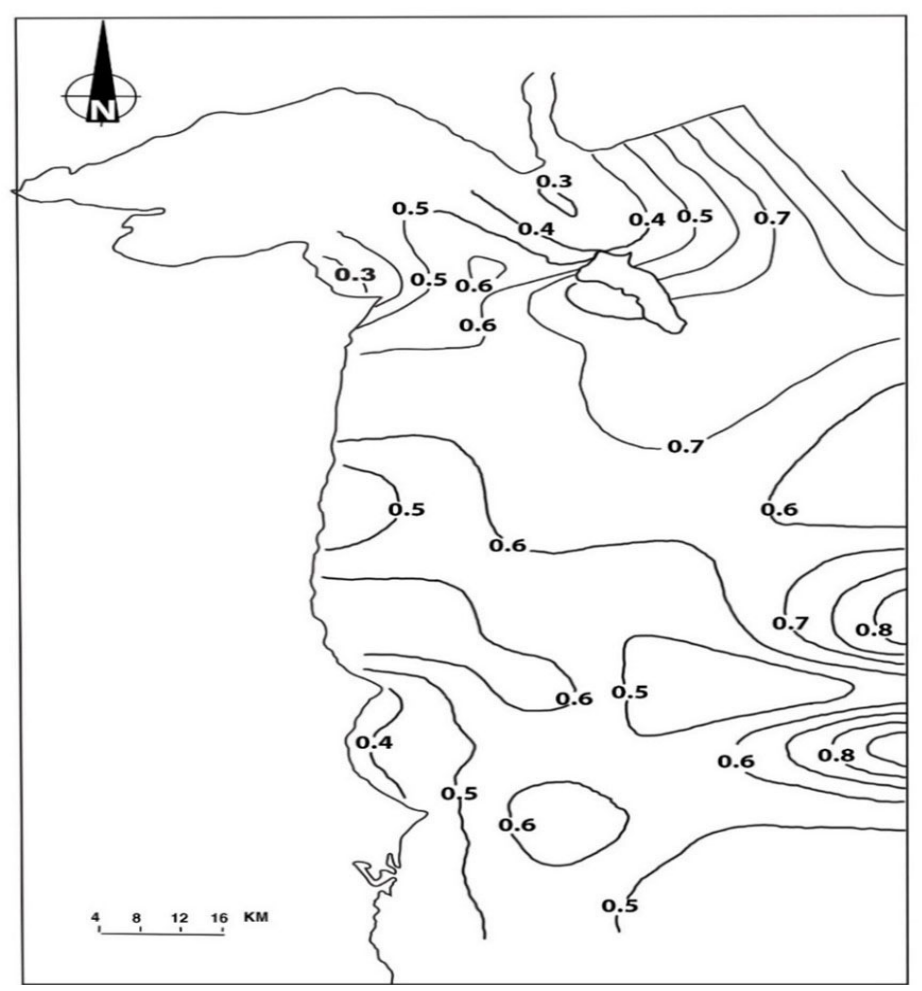

Fig. 4.a. Maximum current contours for neab tides in south coast of Kuwait (Kuwait Meteorological Center, 2014). 


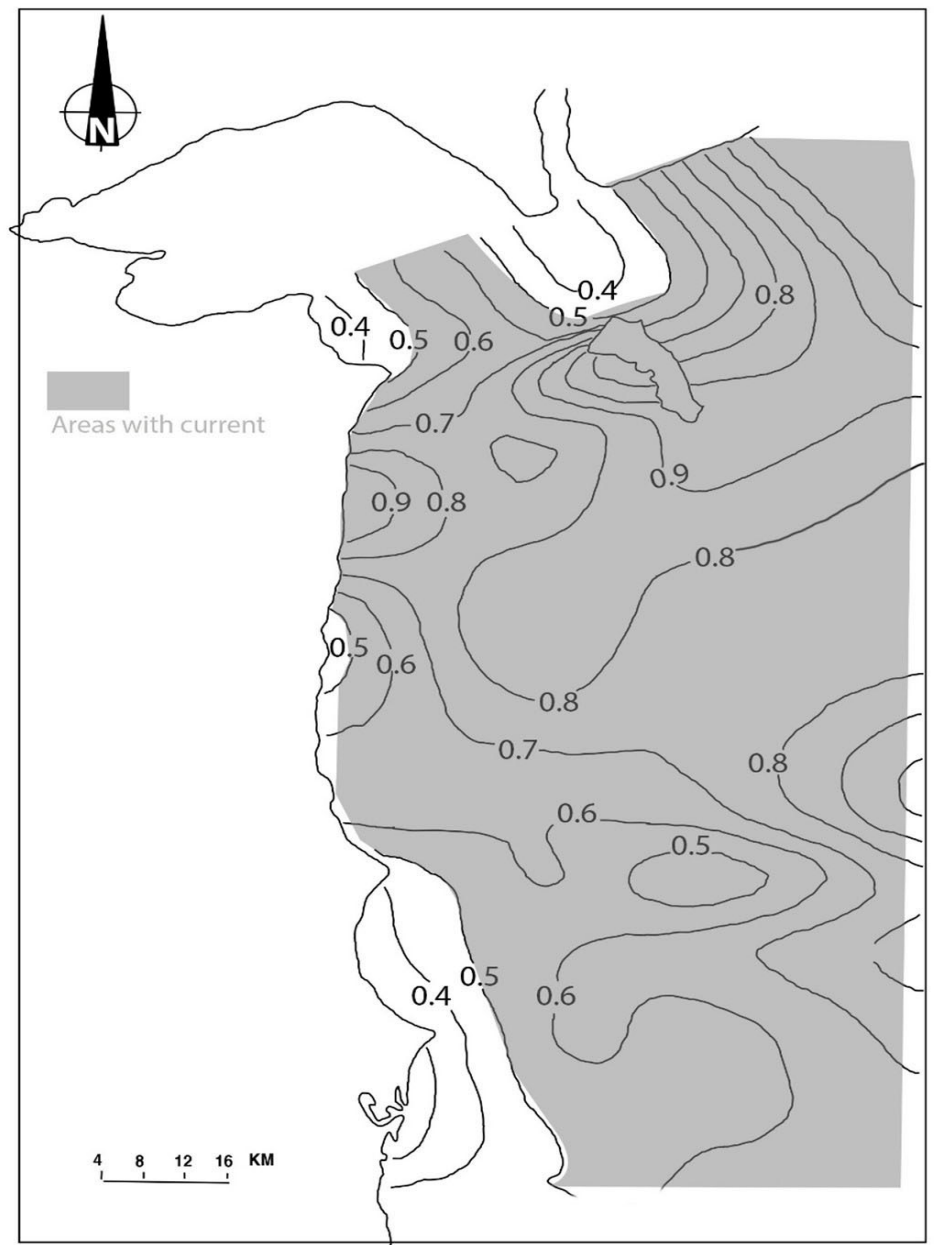

Fig. 4.b. Maximum current contours for spring tides in south coast of Kuwait (Kuwait Meteorological Center, 2014).

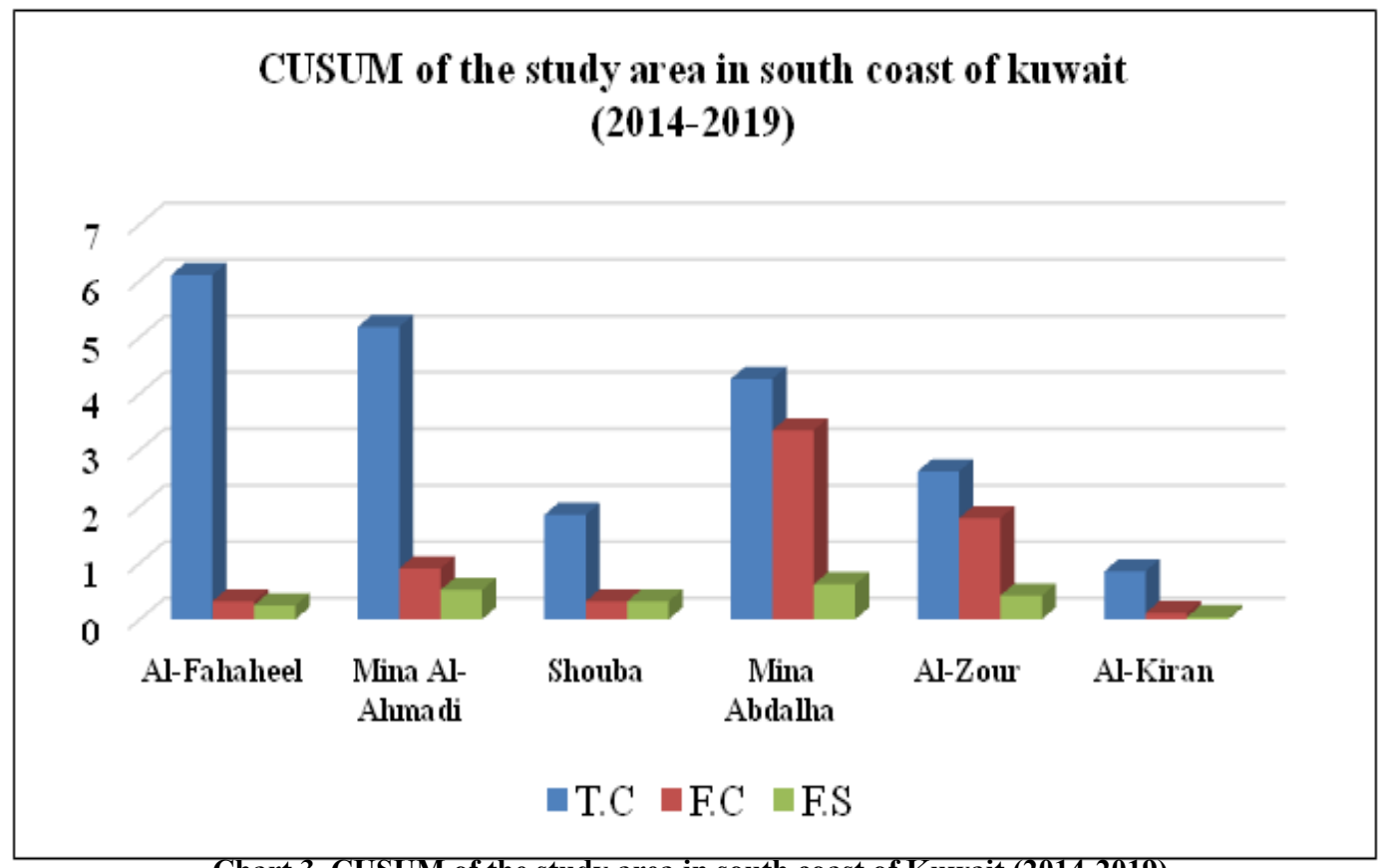

Chart 3. CUSUM of the study area in south coast of Kuwait (2014-2019).

Egypt. J. Geo. Vol. 65 (2021) 
The CUSUM (Barratt et al., 2017) can help to understand which months of the year have abnormal record in the level of pollution in the south coast of Kuwait. Table (1) and Chart (1a) show that the total coliform (T.C), during February has the highest number of bacteria indicators as an average (Table 1). Also, table (2) shows that the total coliform has high values in Mina Abdullah and Al-Zour stations. This can be explained by:

1- The geographic location of those two stations adjacent to south industrial zone in Kuwait (oil refineries, different manufactures, sewage treatment plants). So, the coast area will be at great potential risk of pollution.

2- The tidal waves and current in the Arabian Gulf has low speed due to shape and depth of the body water of the gulf, especially in February. This leads to weak natural cleaning and accumulation of wastes in the marine environmental conditions, hence the total coliform increased. The Fecal coliform (F.C) and Fecal streptococci (F.S) showed the same pattern in February for the same reasons (https://doi.org/10.1016/j. atmosenv.2006.09.052).

\section{Potential pollution public health}

It is a fact that all civilizations and human prosperity largely depend on the waterways like rivers, oceans and gulfs because they have been used to facilitate production, and various recreations facilities.

Unfortunately, the south coast of Kuwait becomes a dumpster for restaurants, yachts club hotels and industry as a result of human activities (Al-Rashed et al., 2019). This fact is evidenced by the values of bacterial indicators. For that substantial Pathogen contamination was developed and accumulated in the lowspeed waves and currents of the coastline. The blooms of these pollutants will pass from food chain in the living biota of sea and the residential land area (Al-Kandari, 1994). Chart (4) shows that cancer diseases was reported to be flourish among the people of Kuwait living in the south (Table 4).

TABLE 4 .Cancer diseases percentage reported by ministry of health (2019) at south Kuwait people.

\begin{tabular}{|c|c|c|c|c|}
\hline Prostate & Colon & Blood & Bone & Breast \\
\hline $40 \%$ & $20 \%$ & $15 \%$ & $10 \%$ & $15 \%$ \\
\hline
\end{tabular}

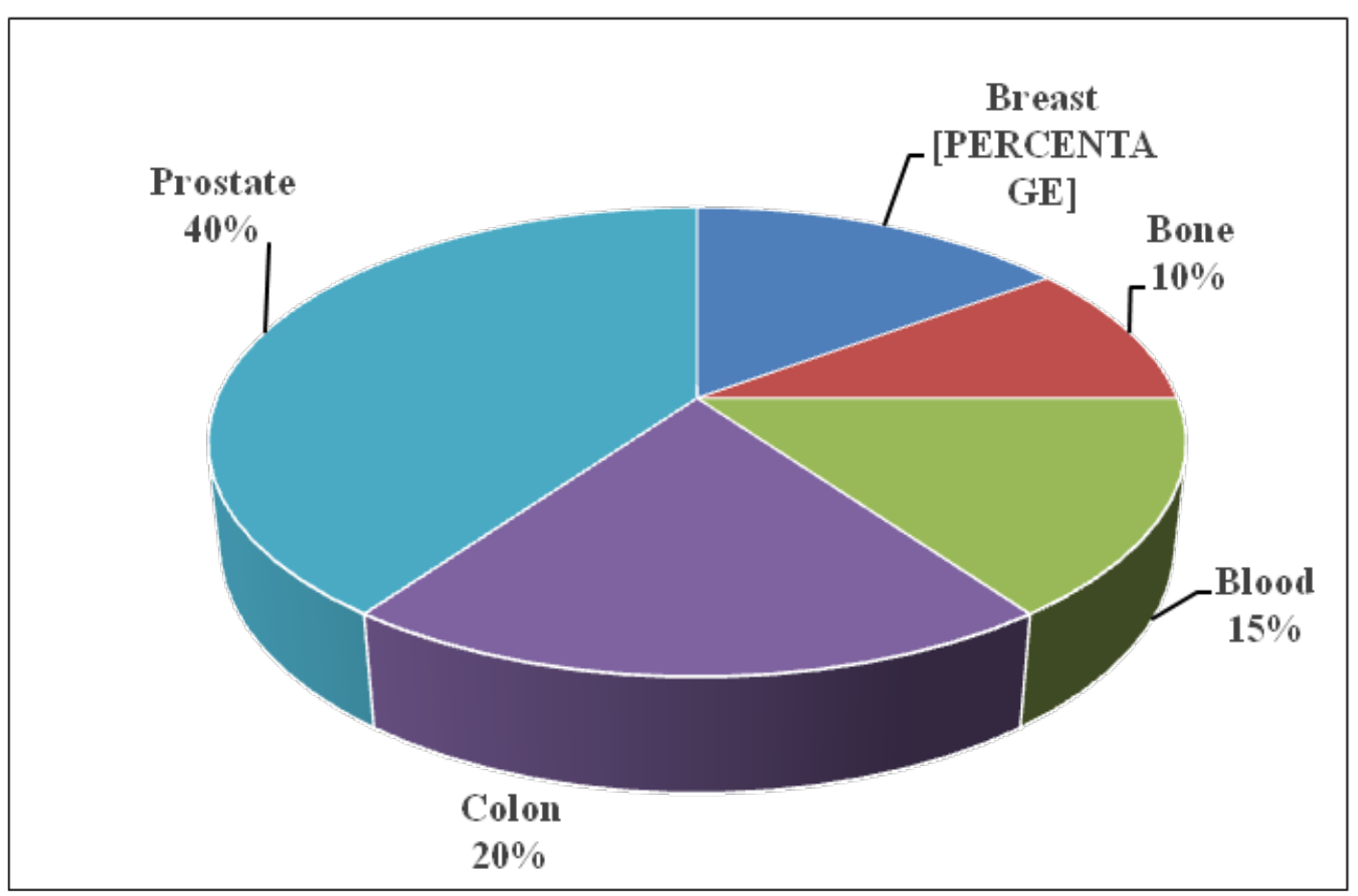

Chart 4. Cancer diseases percentage reported by ministry of health (2019) that infected the people of South Kuwait. 


\section{Conclusion}

The south coastal water analysis showed high level of Bacteria (T.S, F.C and F.S) due to continuous dumping of treated and untreated waters, power plants disposals and different industrial outcomes triggered the pathogen contamination. The coastal waves and currents are crucial for potential environmental risk assessment in the south coast of Kuwait. The CUSUM statistical method can work as trustable tool in estimating and controlling of pollution elimination.

\section{References}

Al-Rashed, A. N., Al-Mutairi, N. and Al Attar, M., (2019) Air Pollution Analysis in Kuwait Using a Statistical Technique (CUSUM). International Journal of Geosciences, v.10-no.3, pp.254-294.

Abou-Seido, M. and ASarawi, M., (1990) Utilization and management of the coastal area in Kuwait Journal of Costal Management, v.18, pp. 385-401.

Al-Kandari, M. H. M. (1994) Evaluation of the Effect of Air Pollution on Human Health in Kuwait. Ph. D. Thesis, London School of Hygiene \& Tropical Medicine, London.

Barratt, B., Atkinson, R., Anderson, H. R., Beevers, S., Kelly, F., Mudway, I. and Wilkinson P., (2017) Investigation into the Use of the CUSUM Technique in Identifying Changes in Mean Air Pollution Levels Following Introduction of a Traffic Management Scheme. Atmospheric Environment, 41: 1784-1791.

Biswas, R. K., Masud, M. S. and Kabir, E., (2016): Shewhart Control Chart for Individual Measurement: An Application in a Weaving Mil. Australasian Journal of Business, Social Science and Information Technology, 2, pp. 89-100.

Ciccio, L., (1998): Water and water pollution Handbook, v.2, Marcel Dekker Inc.

EPA (2019): Integrated coastal zone management, state of Kuwait: Costal environmental profiles, final report, Environmental Public Authority of Kuwait.

Kuwait EPA (2000): Website: www.epa.ku

Kuwait EPA (2017): Website. www.epa.ku

Kuwait Meteorological Center, (2014): Website: https://www.met.gov.kw

Levin, B., and Kline, J., (1985): The CUSUM test of homogeneity with and application in spontaneous abortion epidemiology, journal of Statistics and Medicine v.4 pp. 469-488.
Manly, B. F., and Mackenzie, D., (2000): The power of the $\mathrm{Cu}$ Sum method for environmental monitoring, 12th international Biometric Conference, Berkeley university USA, July 2-7, pp. 15-21.

Manly, B. F. J., (1994): CUSUM methods for detecting changes in monitored environmental variables, University of Otago press, Dunedin, pp. 225-238.

Witherington, L., (2010): Evaluation of CUSUM and EWMA Control Charts to Detect Changes in Underlying Demand Trends of Naval Aviation Spares. Ph. D.Thesis, School of Monterey, California.

WHO (2017): Website https://www.who.int 


\section{استخدام المجموع التراكمي للتقييم البيئي لمياه الساحل الجنوبي للكويت}

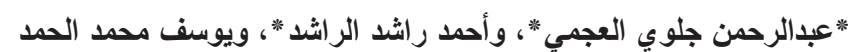

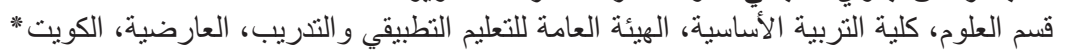

أدى نمو وتطور المناطق الساحلية الجنوبية للكويت نتيجة لارتفاع التصنيع والتحضر إلى فرض إنغ ضغوط شديدة

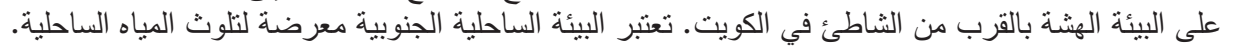

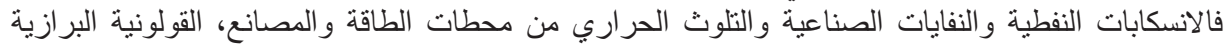

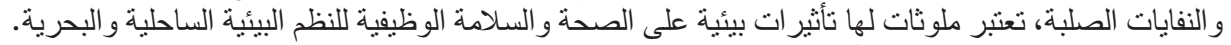

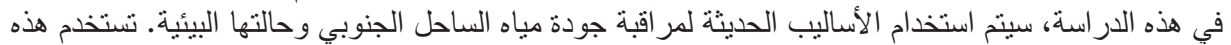

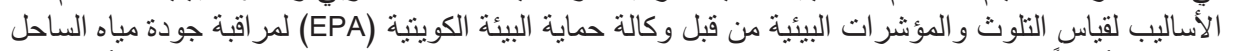

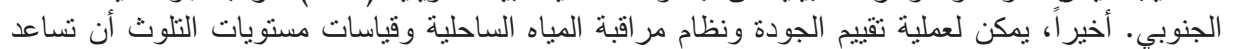

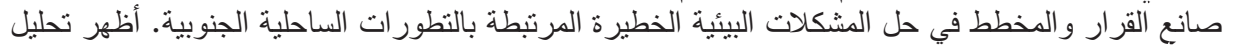
مياه الساحل الجنوبي وجود نسبة عالية من البكتيريا (T.C، F.C، F.S). 